\title{
Karolina Bielenin-Lenczowska
}

Institute of Ethnology and Cultural Anthropology

University of Warsaw

\section{The in-between Generation. Immigrants and the Problem of a Dual Sense of Belonging ${ }^{1}$}

\begin{abstract}
The aim of this paper is an anthropological analysis of three individual biographies of Macedonian-speaking Muslims migrants in Italy. An author focuses on young people who migrated from Macedonia with their parents at the early age. In the literature they are named ' 1,5 generation', while I call them the inbetween gerenation arguing that as immigrants, the people I talked to are between the first and the second immigrant generation, and they find themselves wedged in between the ideas and values of their sending country and the recipient country, and in between childhood and adulthood. They have studied or already completed their education in Italy, they speak Italian fluently and most of their friends are Italian. However, they are still speak Macedonian at home, visit their country of origin every year and are aware of their strong belonging to the Macedonianspeaking Muslim group. Therefore, they should constantly negotiate between traditional values of their parents, and their own patterns of life. The significant issues and tensions regard religious practices, daily habits like food and dress, and - that is most sensitive - gender relations.
\end{abstract}

Key words: Islam; generation; gender relations; Macedonian immigration

\footnotetext{
1 The first version of this paper was translated from Polish by Piotr Szymczak.

This is an Open Access article distributed under the terms of the Creative Commons Attribution 3.0 PL License (creativecommons.org/licenses/by/3.0/pl/), which permits redistribution, commercial and non-commercial, provided that the article is properly cited. (C) The Author(s), 2014

Publisher: Institute of Slavic Studies, Polish Academy of Sciences

Editor in chief: Jolanta Sujecka

Conception and academic editing of this issue: Maciej Falski
} 
7 he Republic of Macedonia has had a long history of economic migration referred to as pechalba in Macedonian (Turkish: a gurbet or kurbet). This kind of labour migration is a long-standing phenomenon in the Balkans, historically attested since the second half of the 19th century when it first took place in the wake of the Crimean wars. Initially, this involved male seasonal economic migration, the men leaving their native areas in spring and summer (from St. George's Day on 6 May until St. Demetrios' Day on 8 November $)^{2}$ to work as hired labourers in agriculture, herding or construction. Pechalba was particularly widespread in the central and eastern Balkans, and pechalbari migrants enjoyed considerable status in their communities. The migrants would flow from poor mountainous regions to more prosperous lowlands and river valleys, taking different routes depending on social and political circumstances. In the Ottoman period, migration from western Macedonia (including the Reka region, which is the main focus point of this article) mainly reached Thessaloniki and Istanbul, before Belgrade became the favoured destination after the Balkan wars. Migrants from eastern Macedonia travelled mainly to Sofia, whereas Albanians tended to migrate to what was then already a free Albania. The early 20th century marked the beginning of migration to the United States and Canada (mostly to avoid military draft), followed by various Western European countries (Hristov 2007). After World War II, men from Macedonia went to various German regions as Gastarbeiter ("guest workers") under an agreement reached by the governments of Yugoslavia and West Germany, as well as, to a lesser extent, Switzerland, the Netherlands and Luxembourg.

My research focuses on the last wave of economic migration in the 1990s and early 2000s. I conducted my research work among Macedonianspeaking Muslims in the Reka region (villages in the municipalities of Mavrovo-Rostushe and Centar Zhupa), who tend to migrate to northern Italy (Ravenna, Treviso) ${ }^{3}$. This region is usually called pechalbarski kraj, i.e. region of pechalba, because of long tradition of this kind of labour mobility. Migration is determined by natural condition of the area. Reka region is rural, mountainous area, where the villages and arable pieces of land are squeezed into a narrow valley of Radika river. Since 1949 the area has been protected as Mavrovo National Park, so the possibilities of using natural resources has been limited. During the period of socialist Yugoslavia, authorities in order to stop the emigration, started to invest in the region. In the 1960s and 1970s

\footnotetext{
The dates are given according to the Julian calendar.

${ }^{3}$ My research was financed by a Polish Ministry of Science and Higher Education grant (Grant No. N109 094839, "Transnational ties, social and ethnic relations in the context of economic migration of Macedonian Muslims from Macedonia to Italy."
} 
a large textile factory in a village of Rostushe was opened, and in Mavrovo on the artificial lake was established a power plant. Some several small factories were opened in the region as well. After 1991, however, factories were closed down and migration again became the main way of earning.

Italy has only recently emerged as a destination for incoming migration, which is apparent in some of the solutions adopted in the country's migration policy. The number of immigrants is particularly high in northern Italy. Northern Italy, and Ravenna commune, where I did my research, is a town with a huge industrial area, while at the seaside (eg. Lido di Adriano, where the rate of migrants from Macedonia is particularly high) the tourism and trade is developed. Male migrants from Macedonia are mainly involved in various kinds of construction work, whereas the women are usually not economically active, and take care of housekeeping and childrearing. Practically none of the pechalbari either farm their own land or keep livestock abroad. Thus, migrants take on more urbanized lifestyles (Hausmaninger, no date) as they move from their rural, agricultural areas to suburbs and towns. It changes not only their daily way of life - dressing, cooking and leisure activities - but also influences the perception of life abroad as a lighter and easier.

According to 2011 data, the commune of Ravenna has a total of 18,238 foreigners (amounting to $11.5 \%$ of the total population). At 1,239 inhabitants, Macedonians account for $6.8 \%$ of the local foreign population, the third largest immigrant group following Romanians and Albanians ${ }^{4}$. A total of 89,900 Macedonian citizens live in Italy, most of them living and working legally. It should be emphasized that this figure comprises Macedonian citizens, which includes Orthodox Christian Macedonians, Macedonian-speaking Muslims, Turks and Albanians. No detailed statistical data are available concerning the exact number of Macedonian Muslims (or Torbeshes), but my research and conversations with members of the community suggest that they constitute the largest bloc in Ravenna's general population of Macedonian citizens alongside Macedonian Albanians.

\section{Differences within the migrant experience}

Differences in the migrant experience are particularly clear in terms of age and gender (Pessar, Machler 2003), but also to education or financial situation. Although the people I talked to realize that the nature of pechalba has changed, today's migration continues, to some extent, to be mostly male and mostly seasonal (Bielenin-Lenczowska 2010). This means that for the

4 http://www.tuttitalia.it/emilia-romagna/63-ravenna/statistiche/cittadini-stranieri-2011/. 
most part only men have income-producing jobs and are relatively wellintegrated into the receiving society (for instance, they speak good Italian and have Italian friends and employers). Women tend to stay at home, and their Italian is in many cases too limited to handle everyday situations such as visits to the doctor or parent-teacher conferences. Although the Italian state organizes free language courses for immigrants (in many towns separate classes for women are also available), many female immigrants do not take them stating reasons such as lack of time or general unwillingness. Lack of motivation turns out to be another factor. Many women are not thinking about getting jobs arguing that our women don't go to work, that their housekeeping responsibilities are too time-consuming for extra income-producing work, and that the economic cri-sis has eliminated many job opportunities. Rather poignantly, one woman said: Even when we're looking for a job, we pray to God (se molime na Alah) that we don't get one. Obviously, men are less likely to be involved in housework or childrearing (although this is visibly changing), so this kind of work falls on women's shoulders. Women are also taught to prepare time-consuming, labour-intensive meals; for instance, many of women I talked to baked their own bread. They also do their own housework, such as cleaning or laundry. Children, particularly sons, are not often involved in housework. Also, migrant women do not have the option of relying on their mothersin-law for help around the house. In this respect, life in Macedonia is easier: conflicts and tensions notwithstanding, a large family living under one roof with means that there are more people to help out with the chores.

Also, female first-generation immigrants are largely poorly educated - most received only primary education in Macedonia, and some had dropped out without finishing. This means that they are unqualified for jobs other than cleaning, babysitting or caring for the elderly, sectors in which they face stiff competition from other immigrants in Ravenna (mainly from Polish women). Moreover, since 2008 on, the economic crisis in Italy has been clearly visible, and finding (or maintaining) a job is more difficult for both men and women.

Numerous scholars (eg. Vertovec 2009, Pessar and Mahler 2003) have pointed to significant change in gender roles and social positions of women and men caused by migration. They often point to the fact that women raise their status as a consequence of migration, while the status of men tends to lower. Meanwhile, my research shows that gender roles are maintained and reproduced after migration and the status of women often deteriorates. Many women live in local (Macedonian-speaking Muslim) enclaves, going about their daily chores just as they used to in Macedonia. This is particularly apparent in terms of interior decoration or cooking, 
but they also reproduce the gender roles or the parent-child relationship from the sending country. Because migrant women tend to be far less involved in public activity compared to Macedonia (although it should be pointed out that female public activity in Macedonia is mainly limited to the domestic sphere), their status is even lower, hurting their perception in the eyes of their much better adapted children. This does not mean that it automatically increases the status of men. It also tends to decrease, since many men have unstable jobs (that is especially visible nowadays, because of the economic crisis).

Nevertheless, women are the ones that prefer to stay abroad. Not just because they are provided with better financial terms, but also because they live beyond the control of the immediate family, especially mothers-in-law. Despite this, they still do work considered feminine, such as housework and raising children, and their willingness to remain abroad is also associated with their urbanization. Namely, living in the city or town they consider lightweight as they do not need to work in the field, they have easy access to shops, schools, restaurants, etc. (cf. Bernal 1997: 134).

The private space of home and daily habits and chores show transnational engagement of women. Similarly, as it is described by Ruba Salih for Moroccan women (2001: 667-668), Macedonian-speaking Muslim women arrange their Italian homes in a way they known from the region of origin, this way reflecting the double belonging. They would bring textiles and various things to decorate from Macedonia, as well as purchase in Italy images of Mecca or inscriptions from the Quran. There is also very noticeable change in food habits. While many would agree that they prefer Macedonian cuisine than Italian, mixing is apparent, for example, it is common to use the Macedonian spices for Italian dishes (cf. Chavez 2006).

\section{The In-Between Generation}

Migration from Macedonia to Italy is quite a recent phenomenon, dating back only as far as the late 1990s and early 2000s. Most of the immigrants are middle-aged or younger. The people I have talked to are mostly firstgeneration immigrants (30-40-year-olds), who came to Italy as adults to start or continue their adult and family lives. Most of them are married and have school- or kindergarten-age children. Some of the people I talked to but these were only males - had already had some experience of immigration when they came to Italy, mostly from working illegally in Slovenia and Italy, especially in the 1990s. As the men said, they first came on their own, and were later rejoined by their wives and children once everything was made ready, i.e. once they had bought or rented an apartment, and 
obtained their work permits and legal immigrant status. The wives did not have to experience the threat of deportation or the insecurity of having to deal with an unresolved immigrant status. But they experienced something that they found equally hard, namely having to live with their in-laws when still living with their husband's families. Families of Macedonianspeaking Muslims are almost without exception patrilocal. Especially in the early stages, a young married woman, often a teenager (Macedonian: nevesta) remains under constant surveillance from her parents-in-law, which frequently leads to tensions and conflicts. A husband may exert a conciliating influence, but when the husbands go off on a pechalba, the girl is left to her own devices. Many of the women I talked to emphasized the difficulty of having to live with their parents-in-law, which they did between getting married and leaving Macedonia, and drew a contrast between living in Macedonia and in Italy. One of them (who will be mentioned a lot in this article) said: Here, they [i.e. Macedonian women] have a good life, they're free, they're on their own. When asked to explain what she meant by "free" and "on their own", she explained that what she meant by that was living without the in-laws, meaning that they lived only with their husbands and children, without having to endure regular meddling. To the women I talked to, this freedom from meddling outweighed the hardships of having to deal with housekeeping and childrearing unassisted. Another point they raised was the fact that they were living in towns now. A vast majority of the men work in construction (where they perform a variety of jobs), and most women - as I mentioned - have no income-producing jobs, so they see urban life as easier and more comfortable.

This article is about the immigrant experience and the problem of a dual sense of belonging - to Macedonia and to Italy - in people who were born in their country of origin but who later emigrated as children. In the literature they are usually referred to as "the 1.5 generation", although this category properly describes children who emigrated with their caretakers (parents, guardians) between the ages of 6 and 12. To use a category coined by Rubén G. Rumbaut (2000), a Cuban-born American sociologist, the people I talked to might be described as belonging to the " 1.25 generation": people between 23 and 30 years of age, educated (or still studying) in Italy, who speak the language well and have Italian friends. In Rumbaut's classification, 1.25 generation immigrants leave their country of origin at the age of 13-17. Like the 1.5 generation, they are not exactly second generation immigrants, but they are certainly not first generation either since most of their childhood, adolescence and socialization took place in the receiving country. In this article, I refer to them as the "in-between generation". For the purposes of my analysis, Rumbaut's classification 
seems to be too fine-grained (in addition to the 1.25 and 1.5 generations he also speaks of the 1.75 generation, i.e. children who were born in the original country but migrated to the recipient country before the age of six). I find the word "in-between" important: as immigrants, the people I talked are between the first and the second immigrant generation, and they find themselves wedged in between the ideas and values of their sending country and the recipient country, and in between childhood and adulthood.

\section{Three biographies}

My research uses the classic ethnographic method of in-depth conversations and participant observation. I purposely favour terms such as conversation and the people I talked to on the one hand to interview, respondent or interviewee on the other. In so doing, I hope to emphasize my personal relationships with people I visit regularly, respect, and meet socially outside of the research context. Our conversations do not consist in asking questions and extracting information: we also negotiate meanings and exchange views and experiences. Only a few of my conversations, mostly with men, could be described as structured interviews, i.e. exchanges scheduled in advance and recorded on a voice recorder. The remaining material comes from spontaneous conversations taking place over a number of meetings. The people I talked to included men and women who are either first- or in-between generation immigrants. Both in Macedonia and in Italy the conversations were conducted in Macedonian, their own language, and then written down and translated. In addition to the conversations, participant observation plays an important part. In the case of my research this involved attending weddings and other celebrations held by pechalbari in Macedonia, preparing meals, watching television together, or visiting mosques.

To tell me their life stories, the people in this article chose the most important moments in their lives. For this paper I have chosen three persons: a 23-year-old unmarried male college student, a thirty-year-old unmarried female social worker, and a 26-year-old married mother of two. All three come from villages in the Reka region and live respectively in Ravenna and its outskirts, and in Treviso. I talked to Ahmed and Ismaila in Italy, and I met Emina personally in Macedonia before conducting a structured interview on Skype. I am also in touch with Ahmed and Emina on Facebook. 


\section{Ahmed $^{5}$}

Ahmed is 23 years old. He has lived with his parents and three younger brothers in a rented apartment in Ravenna for ten years. He will be applying for Italian citizenship this year (2013). ${ }^{6}$. He comes from the village of Rostushe. He has an Italian girlfriend but for the time being he is not planning to get married. He studies International Relations in the nearby town of Forli. Ahmed is very engaged and wants to work for the people of Macedonia; he complains that Macedonians are the only significant ethnic minority in Ravenna without its own association. He is a Muslim and an atheist. I describe below how these two attitudes can be reconciled.

\section{Ismaila}

Ismaila came to Italy in 1998 with her parents. At the time she was in seventh grade, and she went to an Italian school. After completing a preparatory programme involving daily remedial instruction she went on to graduate from a vocational high school specialising in Information Technology. She worked for some time in a shop, currently she is not working. She does not have a job, not even a casual, temporary one. She has been trying to find employment in cleaning houses. Her children (a daughter aged six and a son aged eight) go to school. They commute to a school in the neighbouring town to make sure they are in touch with Italian friends, and the bus connection is very convenient (there is a bus stop opposite the home, whereas locally they would have to be taken to school in a car; Ismaila has a driving license but the family has only one car which is used by her husband most of the time). Ismaila is a Muslim, and she declares that she believes in God but does not attach much importance to religious practice.

\section{Emina}

Emina is a 30-year-old unmarried woman who came to Italy when she was in high school with no Italian. In Italy, she graduated from high school and college, majoring in Social Policy. She works as a social worker on women's rights projects. For a while she worked as a volunteer in an organization for Macedonians. Emina is a Muslim not only by tradition but she is also a practising believer.

Names of the individuals are changed.

6 Under Italian law, an adult may apply for citizenship if he or she has resided in Italy continuously for the past 10 years. Minors become citizens automatically once either of their parents becomes an Italian citizen. 
Several common areas emerged from our conversations, as noted by the people I talked to. These include religion, daily practices, primarily food; the language, and what they believed was the most difficult issue, namely relationships. All those areas are obviously interconnected (for instance, dietary customs are subject to religious prohibitions). It is somewhat artificial to treat those areas separately, and I only do that for the purposes of clarity and structure, and not in order to impose any typologies or classifications.

\section{Religion}

In Macedonia, Muslims include representatives of various ethnic and national communities ${ }^{7}$ : Albanians, Turks, Macedonian-speaking Muslims (Torbeshes), but also Roma people. They are predominantly Sunnis, although there are also some significant tarikats (Dervish brotherhoods), primarily bektashis (Barišić 2007: 32). All of the people I talked to were Sunni Muslims.

My analysis of some of the transformations of religious experience and general perceptions of religious practice follows the inspiration of Steven Vertovec, who said that "[c]omparative research (between 'homelands' and diasporic contexts, or between diasporic contexts) into collective, domestic/ familial and personal modes of religious practice can reveal ways in which, both consciously and inadvertently, ritual may be modified by way of heterodoxy (including syncretism) or, indeed, new forms of orthodoxy" (Vertovec 2003:322).

Immigrant religious practice shows that Islam among the Torbeshi is highly diverse and strongly rooted in Macedonia's local traditions, localities and social and cultural environments. Then, that was noted above, migrants not only leave for another country but they also migrate from the countryside to urban areas. As immigrants, they become urbanised, which affects not only their religious customs but also all of the everyday work rhythms (Hausmaninger no date, Bernal 1997). Nonetheless, they rely on extensive social networks and live in relatively cohesive neighbour communities helping each other, cooperating and staying in touch with each other (in person or using contemporary technology, mostly Facebook).

As put by Ahmed, their Islam is cultural rather than religious, i.e. one can be a Muslim and an atheist, as is the case with Ahmed. The people I talked to abstain from pork, but they sometimes drink alcohol, a fact I discuss in more

In the official discourse the term ethnic or national minority is not used, replaced by community [zaednica]. This was introduced by the framework agreement [Ramkoven Dogovor] signed on 13 August 2001 in Ohrid, which brought an end to the armed conflict between the Macedonians and the Albanians. 
detail in the next section. Steven Vertovec argues that a strict distinction is drawn in diasporas between culture and religion, and between tradition and orthodoxy or othopraxy: "As members of diaspora self-reflect on what is most significant in their religious traditions (that is, what they most wish to pass on their children and what they are most defiant about defending in the face of religious pluralism and/or secularism), many often come to utilise a kind of dichotomy between what elements comprise that which is truly 'religion' (things that are core to their belief and practice) and what elements comprise what amounts to a kind of outer layer of 'culture' (things specific to a particular country or region or linguistic group that actually not affect core beliefs and practices)" (Vertovec 2003: 316). This decision does not need to be judgemental in nature, although it often is.

Of the people I talked to, only Emina prays regularly and considers herself to be a religious person. This does not mean that there are no fervent Muslims in the in-between generation. I also met some people who only became religious after emigrating, and who did not observe the precepts and prohibitions of Islam before they left their country. Emina had been religious before emigrating.

Religious practice in the receiving country or in the country of origin stems from knowledge of Islam. Macedonian-speaking Muslims are not considered as radical in terms of belief or practice, and their knowledge of Islam is limited. Although the five Pillars of Islam (Arkan ad-din, Arkanal-Islam) include religious belief, pilgrimage, almsgiving, fasting during the month of Ramadan and prayer, most of the people I talked to believed the distinguishing characteristics of a religious Muslim to be fasting and abstinence from alcohol and pork; some of them also mentioned prayer. However, Islam is an important element of their distinct identity, from Islamic names to endogamy.

As I mentioned, only Emina prays (klanja). She tries to pray regularly but work often gets in the way. On the one hand, she does not consider Italy to be tolerant enough for prayer breaks to be ensured during working hours (as she puts it diplomatically, the state is not yet ready to accept immigrants). On the other hand, she would never ask for regular prayer breaks as she would not want to be remiss in her duties. She believes that one cannot live today the way people did in Mohammed's time - we must be more flexible (fleksibilni) if we want to work. Accordingly, she fasts when she can. For instance, she once worked with children during the month of Ramadan. During the Ramadan you stay up long into the night. But, she explains, I had to get up in the morning. Without a cup of coffee I can't even take care of myself, let alone of children. 


\section{Language}

All of the people I talked to are fluent in Italian in speech and writing. Free Italian courses are available to every immigrant in Italy. Moreover, separate women-only courses are organised in many places, thus also Muslim women can attend it.

The people I talked to had spoken no Italian before arriving in the country but they all finished Italian schools and none of them had to repeat a single grade. This means that they had to work very hard early on attending extra courses. Now they use Italian on a daily basis to communicate in social and professional contexts. They all speak Macedonian at home, although Ahmed and Emina point out that code-switching often takes place as Italian words or sentences get woven into conversations. In some cases they only communicate in Italian with their younger siblings. Emina remarks that Macedonian is not as rich as Italian, and therefore often uses Italian words to make sure she expressed her meaning precisely. Her comment suggests not so much that Macedonian is a limited language incapable of expressing all ideas (according to structuralists, every language has this sort of flexibility in its own way), but that Emina's linguistic immersion in Italian is greater than in Macedonian, a language she speaks with a distinct Italian accent. Ismaila, who is the only mother among the people I discuss here, struggles with the problem of passing Macedonian to her children. Both her children attend Italian primary schools which do not have many Macedonian pupils. They speak Macedonian at home or to their many Macedonian-speaking neighbours at Lido Adriano. Ismaila says that the children will certainly always feel Macedonian, but they have their friends here, and they only visit Macedonia for three weeks in summer. She assumes that the children will find partners among Macedonian-speaking Muslims, and will keep the language and the tradition this way. As I noticed in another family, second-generation children understand Macedonian very well but they do not speak it well. In one of my conversations when I asked the five-year-old Fuat about his age, he replied in Italian to my question in Macedonian ("Kolku godini imash?” "Cinque").

\section{Food}

Food is an important element of daily life, and food types and patterns of consumption (foodways) are obviously strongly conditioned by culture. The migrants are especially attached to their dietary patterns, and their openness to changing their ways is connected to the extent of their integration within the new environment. For my interlocutors, food brought from Macedonia 
or dished prepared in Macedonian way are typical comfort food - connected to positive memories, nostalgia and home (cf. Locher et al. 2005). Migrants listed their favourite dishes unhesitatingly: coffee, ajvar, pâté, sausage. Some bring kori from Macedonia, a thin and flaky pastry used in layers, similar to puff pastry. Kori is the basis for baklava (a sweet dessert containing nuts prepared for major holidays) and pita (dough filled with cheese, meat or vegetables such as leeks, spinach or nettles). Emina also mentions yoghurt and sirenje (a salty cheese made of sheep's milk, similar to Greek feta), products which must be consumed relatively quickly. Importantly, two of the people I discuss in this article, Emina and Ahmed, still live with their parents, where their mothers are in charge of the cooking. Ismaila, who has a family of her own, likes to experiment with Italian dishes. She says: it's good when you learn something new. When she was taking her Italian classes she says the participants organised a farewell party and came with their national/regional dishes: it's very good if you can get to know another culture and other people's ways, she concludes. In the homes of Emina and Ahmed the food is sometimes Italian and sometimes Macedonian - about equally, Ahmed believes. When I was having a conversation with Emina over Skype and asked her what she had had for lunch, she said: today we had spaghetti, it was Italian food today.

The people I talked to are used to Macedonian cuisine, especially Macedonian coffee. Many of the men I talked to said that they preferred the stronger Italian-style coffee, whereas their wives only drank Macedonianstyle coffee (Turkish style, brewed in a small pot called džezva). I can confirm that I was offered Turkish coffee every time I visited women. Emina said that espresso was usually the coffee of choice in her home, but they also brought coffee from Macedonia for visitors. Everybody imports ajvar, a mild or spicy pepper paste with garlic, tomatoes and aubergine served with bread, meats and cheeses, which is one of the most popular preserved foods during the winter season. Ajvar is prepared in early autumn: in late September and early October there is hardly a Macedonian house where the air is redolent of baking peppers. In pechalbari villages, ajvar is made in August when the pechalbari come to Macedonia. The migrant women make it themselves, put it in glass jars and take it to Italy, Germany or Switzerland.

All of the people I talked to were Muslims, and although dietary prohibitions are not one of the pillars of Islam, they often mentioned them in the first place as distinguishing characteristics of the faith. Whether in Macedonia or in Italy they all confirm that they abstain from pork and alcohol and observe their fast. However, those rules are often interpreted in quite liberal ways. For instance, my field notes from February 2011 contain 
the following observation: "Omran comes to visit Dragica and Goran to drink some rakia. When I goad him, 'What, a Muslim drinking alcohol?' he replies in a serious tone: Everything is for people. But you know, I don't drink five or six glasses, only one or two. Quite a lot of men drink beer (Muslim women usually abstain from alcohol completely; very occasionally they smoke cigarettes, usually on the sly to keep the secret from their husbands). Interestingly, Muslim men in Macedonia did not tend to offer me alcohol but in Ravenna (away from prying eyes?) most of my conversations with men would take place over a glass of beer. Ahmed had this to say about offering alcohol: They'll be saying, be one of us [ajde da bidesh nash], have some rakia, have some beer. Wine is not consumed - it's too Christian, it's associated with the mass, the blood of Christ, we don't have that in our culture. The comment, ajde da bidesh nash - be ours, be one of us - shows the extent to which the Islam of Macedonian-speaking Muslims is cultural in nature.

Emina too notes the difference between what is traditional and what is key to the Islamic tradition. She believes that drinking alcohol is obviously not a good thing. If people believe that eating pork is wrong but drinking alcohol is not, that is a contradiction. But she also believes that trying to live strictly in accordance with the Koran is too radical, and shows a failure to adapt to the modern conditions of life.

In one of the western Macedonian villages I visited, there was only one shop selling alcohol throughout the year (interestingly, the shop was located opposite the police station). In August, however, when the pechalbari come back to Macedonia, two shops and two restaurants were serving beer. Ouzo and other kinds of alcohol are also sold under the counter. Because travellers need not observe fast, many men run errands in the nearby town during the month of Ramadan to interpret their trips as "travelling" and find an excuse to visit a restaurant.

The concept of halal is not generally known. When I ask people about halal foodstuffs or cosmetics, they often have no idea what I am talking about: I just buy the meat in the supermarket, just as long as it's poultry or beef. I never buy pork. When I told one of the women that there were special shops for Muslims she said that those were too expensive (although she admitted that she had never been to a shop of that kind, and did not understand the concept of special shops). Emina is familiar with the concept of halal, but she does not buy in such shops. During the holidays (Bayram Kurban and Ramazan Bayram) she only eats meat prepared in accordance with Islamic laws, buying meat portions prepared in Muslim slaughterhouses. In Italy such slaughterhouses are usually run by immigrants from Morocco. 


\section{Relationships and gender relations}

Forming relationships and negotiating the gender relations in general was the hottest topic in my conversations, connected with a changing understanding of male and female gender roles and desirable and undesirable behaviours; in other words, the clash between "our own" (traditional) ways and "their" (alien) ways.

According to 19th-century sources, pechalbari villages were endogamous, the migrants returning to their native villages and finding partners there. Pechalbari reunions were a time for wedding parties, which provided an opportunity for meeting new partners. Many of the marriages were arranged by the parents, who were familiar the local families and knew whether or not a couple would be related by blood, which removed ineligible candidates from the equation.

Villages in the region of Reka continue to be endogamous. Being Muslim is an important consideration in terms of eligibility, but so is locality, a local partner (a Nashinec) being preferable. August, the month when the migrants come to Reka (some would even describe it as "return to Reka"), is also a time for major family celebrations, and several festivities are held in every village every day. All the villagers are invited to weddings regardless of their religious identity, and they are offered food. Nowadays, wedding parties are often held in restaurants, but many elements of those celebrations take place in the home village (or villages) of the newlyweds. When asked why they did not organize their wedding parties abroad, the pechalbari tended to explain that doing so would be too expensive. But more importantly, holding a wedding party in Macedonia means that Roma musicians from the local town of Debar can be hired for the wedding party, the women may wear the traditional costume (nosija), and special dishes can be prepared. Also, as I mentioned, the whole village population gets invited to a wedding party since wedding parties provide an young people with an opportunity to meet, people-watch and gossip. Wedding parties in western Macedonia are very lavish, and being able to hold a celebration significantly reflects on the family's social status (Bielenin-Lenczowska 2010).

Religious endogamy is also practised in villages in western Macedonia with mixed Muslim and Orthodox Christian populations. The inhabitants are very careful to establish relationships which will ensure a good and conflict-free coexistence between neighbours (cf. Lubaś 2011).

Religious and ethnic endogamy also applies to migrants. Interestingly, even Ismaila, who is very open to diversity, points out that her children would find it hard to deal with a partner from a different background. Since there are so many of our boys and girls living in the area, she 
assumes that her children will be able to find partners easily. Similarly, Ahmed has an Italian girlfriend but he realises that when the time comes to start a family of his own, marrying her will not be easy. Actually, they [the parents] will want a nashinka (a girl of our own). He points out that Islamic identity is predicated on cultural rather than religious grounds. It doesn't matter whether [I were to marry] a Christian girl or a Moroccan girl. Personally, Ahmed is of a different opinion, and has no problem with his girlfriend being Italian, but he has not yet taken her to Macedonia to avoid ruffling too many feathers. Being in a less serious relationship is not a problem, but when the time comes [to get married], my parents will start complaining. Emina who dates a Torbesh boyfriend, has this to say about mixed relationships: I am a Muslim, and we have this law that the wife must accept her husband's religion. If I were to fall in love with an Italian, that would mean losing all of my tradition, all of my religion. Emina is a religious Muslim, but when I ask her whether she would consider marrying a Muslim from a different country (such as a Moroccan, the Moroccans being one of the larger immigrant groups in Italy), she too takes note of the cultural aspects: Look, our parents are making efforts to ensure that the children hold on to our customs, traditions. Especially among us, immigrants. Differences in many cases bring about discord, conflict, even violent death. This is not just a matter of religion, people have different mentalities.

Young migrants also experience tensions caused by the way they tend to spend their free time, make friendships (including friendships in school and at work) or generally conduct themselves in public space, which stems from different ideas about male and female gender roles and differences in the general understanding of what a relationship between two people should entail.

Because the local press is quick to criminalise migrants and to perpetuate negative stereotypes, problems involving family tensions tend to be quite reliably reflected in press reports. Leonora Jahja of Treviso is one named example of such a media story: the 21-year-old woman was in love with an Italian Catholic (who requited her feelings) and she experienced physical abuse at the hands of her parents, including attempted kidnappings and death threats. The woman did not give up and pressed criminal charges against her parents. She moved in with her boyfriend, got married and converted to Catholicism. She is planning to write a book, which she hopes will help other girls like her to make independent decisions about their future and their identity.

Another example is the 19-year-old woman of Sulmona who moved in with her Italian Catholic boyfriend. In order to break up their relationship, the woman's parents kidnapped their daughter, planning to traffic her to 
Macedonia. Momentarily unattended, the woman managed to send a text message to her boyfriend, who immediately alerted the police. The woman's father was arrested. Another example comes from the area of Treviso, where a young woman was beaten up by her brother because he believed her lifestyle and her fashion sense to be "too Western". The same brother had also beaten up his sister's Italian boyfriend. There are many more instances of physical violence targeted at people with "Western lifestyles".

The category of Western/non-Western is worth dwelling on in terms of its axiology and various meanings. As many Balkan scholars have pointed out, despite being geographically part of the European continent the region is often shown as somehow opposed to Europe and the West. It is something of a truism to say that the Balkans are more of a mental category then a geographical location, so I just want to draw attention to how some constructions prove to be long-lasting and get perpetuated in various situations. When conducting her research among the young female engineers in 1990s Skopje, the anthropologist Ilka Thiessen (2007) noted how often they used categories such as "the West" or "the Balkans" when they wanted to describe their attitudes and opinions about the world. For instance, "Western" attitudes would include women's rights, and "Balkan" attitudes would involve women staying out of the public sphere and bearing many children. Punctuality and working in a young, ambitious team were "Western", whereas lack of punctuality, cronyism and corruption were "Balkan". According to Thiessen's respondents, young people in Macedonia tend to be more "Western" and older people more "Balkan"; Orthodox Christians in Macedonia are "Western", whereas Albanians (Macedonia's largest ethnic minority) are "Balkan". This is a problem which needs to be tackled by the young Republic of Macedonia, which following the dissolution of Yugoslavia found itself in the geographical heart of the Balkans but strives to be Western and modern.

The category of Western/non-Western takes on a new meaning in discussions with and about immigrants from Macedonia. Many of the people I talked to use this category interchangeably with modernity, civilisation and culture to emphasise their own worldly sophistication (Jas sum moderen). Emina, for instance, describes her own parents as modern (moderni). In contrast to adjectives such as modern or Western, there are words such as backward (zaostanat), which the people I talked to believed were descriptive of the mentality, behaviours and lifestyles of people who never emigrated. For instance, respecting the law is modern (and therefore civilised and Western). One of the young men said: Here [in Italy] they've got culture. You can't throw your rubbish out in the street. You'll get penalised immediately. But there [in Macedonia], just look at the state of things, it's chaos. 


\section{Conclusions}

The in-between generation describes people who left their country as teenagers. They completed (or are in the process of completing) their education abroad, which is where they met most of their friends, and they are fluent speakers of the receiving country's language.

This article analyses the biographies of three people aged 23-30. They are Macedonian-speaking Muslims from western Macedonia living in northern Italy. They all came to Italy speaking no Italian, coming with their parents and siblings.

The people I talked to unambiguously describe themselves as Macedonians and Muslims (which means a person with a Muslim name brought up in a Muslim family, but not necessarily a religious person), coming from western Macedonia but strongly attached to Italian language and culture. Their lives are lived in Italy where they study or work and have Italian friends, but they continue to treat their native country/region as a kind of point of reference. This is particularly noticeable in the way they remain attached to the Macedonian ways in their daily life, such as food or the preservation of the Macedonian language, but also in religious practice, which has a clear local colouring and draws a strong distinction between religion and culture. Although they are all Muslims, many people drink alcohol, and women do not go to the mosque. Above all, local Islam from the region of Reka in Macedonia is treated as an element of identity and the main criterion when looking for partners. For this reason, the immigrants practice religious and ethnic endogamy, and the major family celebrations - primarily lavish weddings - are held in Macedonia under the watchful eye of the local community.

Conversations with representatives of the in-between generation reveal what matters to them the most in terms of understanding their own identity. They reflect on the views and lifestyles of their parents, and they observe the new environment of the receiving country in which they are becoming increasingly immersed. They analyse and appraise it using the opposition modern - backward, where modern also means Western. The clashing cultural contexts result in tensions and conflicts within families, but they also show the various ongoing social and cultural changes in family life. Those changes affect elements of daily life, such as kitchen management, but also relationships between the sexes or the position of the various family members. 


\section{References}

Bernal Victoria (1997). "Islam, Transnational Culture, and Modernity in Rural Sudan.” In: Maria Grosz-Ngate and Omari Kokole (eds.), Gendered Encounters: Challenging Cultural Boundaries and Social Hierarchies in Africa. New York and London: Routledge Press.

Bielenin-Lenczowska Karolina (2010). Peczalbarskie wesele - prestiż, tradycja i więzi rodzinne w zachodniej Macedoni. In: Radkowska-Walkowicz Magdalena, Malewska-Szałygin Anna (eds.). Antropolog wobec wspótczesności. Tom w darze Profesor Annie Zadrożyńskiej. Warszawa: 395-411.

Chavez Leo (2006). Culture Change and Cultural Reproduction: Lessons from Research on Transnational Migration. In: Janice E. Stockard and George Spindler (eds.), Globalization and Change in Fifteen Cultures: Born in one World and Living in Another. Belmont, CA: Thomson-Wadsworth.

Guarnizo Luis Eduardo (1997). "The Emergence of a Transnational Social Formation and The Mirage of Return Migration Among Dominican Transmigrants," Identities: Global Studies in Culture and Power, 4(2).

Hristov Petko (2005). "The Market and the Piazza for Hired Hand in Sofia as Places to Exchange Cultural Stereotypes," Ethnologia Balkanica Issue 9.

Hristov Petko (2008). "Family and migrations in the Balkans (19 ${ }^{\text {th }}$ and $20^{\text {th }}$ century)." In: Ionela Băluță, Constanța Vintilă-Ghițulescu, Mihai-Răzvan Ungureanu (eds.) Social Behaviour and Family Strategies in the Balkans $\left(16^{\text {th }}-20^{\text {th }}\right.$ Centuries). Bucharest: New European College.

Locher Julie L., William C. Yoels, Donna Maurer, Jillian van Ells (2005). „Comfort Foods: An Exploratory Journey Into The Social and Emotional Significance of Food", Food and Foodways: Explorations in the History and Culture of Human Nourishment, vol. 13, issue 4.

Lubaś Marcin (2011). Różnowiercy. Wspótistnienie międzyreligijne w zachodniomacedońskiej wsi. Studium z zakresu antropologii społeczno-kulturowej. Kraków: Nomos.

Maeva Mila (2010). “The Processes of Labour Mobility and Emigration of Macedonian Muslims (Torbeshes) to Central and Western European Countries.” In: Petko Hristov (ed.) Balkan Migration Culture: Historical and Contemporary Cases from Bulgaria and Macedonia. Sofia: Paradigma.

Marcus George E. (1995). "Ethnography in/of the World System: The Emergence of Multi-Sited Ethnography," Annual Review of Anthropology, 24.

Pessar Patricia, Mahler Sarah (2003). "Transnational migration: Bringing gender in," International Migration Review 37(3).

Rumabut Rubén G. (2010). "Ages, Life Stages, and Generational Cohorts: Decomposing the Immigrant First and Second Generations in the United States," International Migration Review 38 (3).

Salih Ruba (2001). "Moroccan migrant women: transnationalism, nation-states and gender", Journal of Ethnic and Migration Studies. 27 (4).

Salih Ruba, Riccio Bruno (2011). "Transnational Migration and Rescaling Processes. The Incorporation of Migrant Labor.” In: Nina Glick Schiller and Ayşe Çağlar 
(eds.) Locating Migration. Rescaling Cities and Migrants. Ithaca and London: Cornell University Press.

Thiessen Ilká (2007). Waiting for Macedonia. Identity in a Changing World. Toronto: University of Toronto Press.

Vertovec Steven (2003). "Diaspora, Transnationalism and Islam: sites of change and modes of research." In: S. Allievi, J. S. Nielsen (eds.). Muslim Networks and Transnational Communities in and across Europe. Leiden: E.J. Brill.

\section{Web references}

http://www.abruzzo.tv/news/sulmona-rapita-dalla-famiglia-ragazza-macedoneinnamorata-di-un-italiano-arrestato-il-padre-16304(access: 20.05.2013).

http://www.blitzquotidiano.it/cronaca-italia/treviso-ragazza-macedone-picchiata-dalfratello-viveva-alloccidentale-969961/

http://tribunatreviso.gelocal.it/cronaca/2011/05/10/news/picchiata-per-il-mioamore-cattolico-1.1564421 (access: 20.05.2013).

\section{Pokolenie pomiędzy. Imigranci a problem podwójnej przynależności}

Celem artykułu jest antropologiczna analiza biografii trojga macedońskojęzycznych muzułmanów, należących do grupy imigrantów we Włoszech. Autorka skupia się na młodych ludziach, którzy na wczesnym etapie życia wyemigrowali z Macedonii z rodzicami. W literaturze nazywa się ich „pokoleniem 1,5 ”, podczas gdy w omawianych badaniach wybrano termin „pokolenie pomiędzy”; ponieważ rozmówcy jako imigranci znajdują się między pierwszym a drugim pokoleniem imigracyjnym, są zawieszeni pomiędzy wartościami i ideami kraju pochodzenia i kraju przyjmującego, pomiędzy dzieciństwem i dorosłością. Studiowali lub ukończyli edukację we Włoszech, mówią płynnie po włosku, a większość ich przyjaciół to Włoszki/Włosi. Jednak wciąż mówią po macedońsku w domu, co roku odwiedzają kraj pochodzenia i mają silną świadomość przynależności do grupy macedońskojęzycznych muzułmanów. Z tego względu wciąż muszą prowadzić negocjacje między tradycyjnymi wartościami rodziców a własnymi wzorami życia. Znaczący problem i źródło konfliktów stanowią praktyki religijne, elementy kultury codzienności, takie jak ubiór czy pożywienie, oraz - co najbardziej drażliwe - relacje genderowe. 